\title{
Characterisation of Levonorgestrel-Resistant Endometrial Cancer Cells
}

\author{
Molly Dore' \\ Sara Filoche' \\ Kirsty Danielson ${ }^{2}$ \\ Claire Henry (D) ${ }^{1}$ \\ 'Department of Obstetrics, Gynaecology \\ \& Women's Health, University of Otago, \\ Wellington, New Zealand; ${ }^{2}$ Department \\ of Surgery and Anaesthesia, University of \\ Otago, Wellington, New Zealand
}

Correspondence: Claire Henry Department of Obstetrics, Gynaecology and Women's Health, University of Otago, Wellington, New Zealand Tel +64220926984

Email Claire.henry@otago.ac.nz
Background: Endometrial cancer (EC) is the most common gynaecologic malignancy in the developed world, and incidence is increasing in premenopausal women. The levonorgestrel intrauterine system (LNG-IUS) is gaining traction as an alternative treatment for hyperplasia and early-stage EC for women who are unable to undergo surgery. Thirty to $60 \%$ of the women do not respond to this treatment, making the unknown mechanisms of levonorgestrel (LNG) resistance a critical obstacle for the conservative management of EC. This study aimed to characterise LNG-IUS treatment resistance in early-stage endometrial cancer in cell-line models. Methods: LNG-resistant endometrial cancer cell lines $\left(\mathrm{MFE} 296^{\mathrm{R}}\right.$ and MFE319 ${ }^{\mathrm{R}}$ ) and cultures from three early stage endometrial cancer patients were developed. The behavioural profile of MFE296 ${ }^{\mathrm{R}}$ and MFE319 ${ }^{\mathrm{R}}$ was analysed using proliferation, adhesion, migration (wound healing and transwell) and invasion (spheroid) assays. LNG-sensitive cell lines $\left(\right.$ MFE296 $^{\mathrm{S}}$ and MFE319 ${ }^{\mathrm{S}}$ ) were compared to LNG $^{\mathrm{R}}$ cell lines $\left(\mathrm{MFE} 296^{\mathrm{R}}\right.$ and MFE319 ${ }^{\mathrm{R}}$ ). A literature search was conducted to identify possible candidate biomarkers of LNG resistance. RT-qPCR was used to analyse the mRNA expression of 17 candidate biomarkers in MFE296 ${ }^{\mathrm{R}}$ and MFE319 ${ }^{\mathrm{R}}$. mRNA expression of the top differentially expressed genes was measured using RT-qPCR in primary cultures.

Results: LNG resistance did not affect proliferation or invasion in immortalised endometrial cancer cells. Transwell migration was significantly increased in MFE319 ${ }^{R}$ cells $(p=0.03)$. Cellular adhesion significantly decreased in both MFE296 ${ }^{\mathrm{R}}$ cells $(\mathrm{p}=0.012)$ and MFE319 cells $(p=0.04)$. mRNA expression of KLF4 and SATB2 was significantly amplified in MFE296 ${ }^{\mathrm{R}}$ and MFE319 ${ }^{\mathrm{R}}$ cells. mRNA expression of KLF4 was significantly upregulated LNG-resistant primary cell lines.

Conclusion: LNG-resistant cells may have more oncogenic potential than their LNGsensitive counterparts. Significant changes in the mRNA expression of KLF4 and SATB2 of LNG-resistant cells is a promising preliminary result in biomarker discovery for guiding LNG-IUS treatment of early stage endometrial cancer.

Keywords: endometrial cancer, biomarker, therapy, response, levonorgestrel-releasing intrauterine system

\section{Background}

Endometrial cancer (EC) is the most common gynaecologic malignancy globally contributing to $3.9 \%$ of the total cancers in women. ${ }^{1} \mathrm{EC}$ is generally diagnosed at earlier stages, with $75 \%$ of EC cases being classed as low-grade endometrioid EC (EEC) histological subtypes. ${ }^{2,3}$ Currently, the standard treatment for early-stage EEC is a hysterectomy and a bilateral salpingo-oophorectomy ${ }^{4}$; however, up to $25 \%$ of EEC patients are premenopausal, with $5 \%$ of these women being under the age of $40 .{ }^{4,5}$ Furthermore, women with a high BMI are more likely to be diagnosed 
with EEC, ${ }^{6}$ however, up to $10 \%$ of these women are deemed inoperable. ${ }^{7}$ This data, alongside a shift in global demographics resulting in the rising prevalence of both ageing populations and obesity; ${ }^{8-10}$ has led to an increase in the incidence of EEC in inoperable women. This shift is increasing the demand for conservative management options for EEC.

Until recently, systemic progestogen therapy, such as medroxyprogesterone acetate (MPA), has been used for conservative management of EEC. MPA has proven to be efficacious in the treatment of hormone-sensitive tumours in women where surgery is not a treatment option. ${ }^{11}$ However, new evidence is shifting the conservative management of EC towards a long-acting reversible contraceptive device, the levonorgestrel intrauterine system (LNG-IUS). The LNG-IUS is currently used to treat women with abnormal and heavy bleeding (menorrhagia) as levonorgestrel (LNG) (a synthetic form of progesterone) suppresses endometrial proliferation through counteracting the effect of oestrogen. ${ }^{12}$ The evidence base for the use of the LNG-IUS when treating EEC appears promising, with treatment in this setting yielding response rates between $52 \%$ and $67 \%$. $^{13-16}$ Compared with oral progestogens, the LNG-IUS has a similar disease regression rate and is associated with fewer systemic adverse effects due to being placed locally in the uterus. ${ }^{17}$ Still, the evidence appears that there is inconsistency in response when using the LNG-IUS for treatment of early-stage EC in some women making the unknown mechanisms of LNG resistance a critical obstacle for the conservative management of EC.

Currently, the absence of predictive biomarkers for LNG-IUS treatment of early-stage EC limits the certainty of recommendation, ${ }^{18}$ with both response and monitoring of treatment depending on invasive biopsies every 3-6 months. ${ }^{4}$ In recent years, researchers have investigated a variety of approaches for predicting response to conservative treatment of $\mathrm{EC}$; however, few papers investigate predictive biomarkers involved in LNG-IUS resistance explicitly, ${ }^{19}$ with only three looking at the effects of the LNG-IUS in women with EC. Our recent review comments on the current status of predictive biomarkers in LNG-IUS treatment of EC and hyperplasia ${ }^{19}$ and highlights the importance of biomarkers in LNG-IUS treatment of EC. Low protein expression of $\mathrm{HE} 4^{14}$ and progesterone receptorB ${ }^{20}$ alongside $\mathrm{mRNA}$ expression of $F O X O 1^{21}$ have all been identified as possible predictive biomarkers of non-response to the LNG-IUS specifically. One of the largest-scale genetic-based studies done to date on the topic was conducted by $\mathrm{Li}$ et al, who observed upregulated mRNA expression of ANO1, SOX17, CHNL1, DACH1, RUNDC3B, SH3YL1 and CRISPLD1 in an Ishikawa progesterone resistant cell line. ${ }^{22}$ This study observes this occurrence in one commercial cell line and is based on MPA resistant cells, rather than LNG-resistant cells Additional research into genes implicated in progesterone resistance is clearly warranted and as currently, there are no predictive biomarkers used clinically in relation to LNG-IUS treatment.

This study aimed to identify differentially expressed genes (DEGs) in LNG-resistant cells compared to LNGsensitive cells and to build a behavioural profile of LNGresistant cell lines. These DEGs may then go on to serve as potential predictive biomarkers to be investigated further in patient cohorts.

\section{Methods \\ Cell Culture}

Endometrioid EC cell lines MFE296 and MFE319 were cultured as per the supplier's recommendations: MFE296 in Minimum Essential Medium (MEM) (Gibco; Thermo Fisher Scientific \#11095-080, CA, USA) containing 10\% foetal bovine serum (FBS) (Gibco; Thermo Fisher Scientific \#10-091-148, CA, USA) and MFE319 in 1:1 MEM/Roswell Park Memorial Institute Medium (RPMI 1640) (Gibco; Thermo Fisher Scientific \#11875-093, CA, USA) containing $20 \%$ FBS. All media were supplemented with $100 \mathrm{U} / \mathrm{mL}$ penicillin/streptomycin (Gibco; Thermo Fisher Scientific, \#15070-063, CA, USA). Cells were grown in $5 \% \mathrm{CO}_{2}$ at $37^{\circ} \mathrm{C}$. Cells were confirmed negative for mycoplasma.

\section{Ethics}

The current study used primary cells derived from tissue samples of early-stage EC cultures donated by women as part of the Gynaecological Cancer Tissue Bank at Wellington hospital (Health and Disability Ethics Committees (HDEC) 15/CEN/143 and University of Otago health ethics committee $\mathrm{H} 20 / 002$ ). All patients provided written, informed consent prior to donation to the biobank.

\section{Primary Cell Lines}

The isolation of adenocarcinoma cells from cancerassociated stromal cells was carried out according to 
previous studies. ${ }^{23}$ A section of endometrial cancer tissue (5-20mm) was dissociated for 1 hour using collagenase type I (Sigma-Aldrich \#C0130-500MG, NSW Australia) $(10 \mathrm{mg} / \mathrm{mg})$ in TESCA buffer $(50 \mu \mathrm{M}$ TES; $0.36 \mu \mathrm{M} \mathrm{CaCl})$ (Sigma-Aldrich \#T1375-100, NSW Australia) diluted to $0.5 \mathrm{mg} / \mathrm{mL}$ in PBS and DNAse 1 from bovine pancreas (Sigma-Aldrich \#DN25, NSW Australia) diluted to $0.1 \mathrm{mg} /$ $\mathrm{mL}$ in PBS. Cell solution was passed through a $40 \mu \mathrm{m}$ cell strainer to separate cancer-associated stromal cells from adenocarcinoma cells. Cancer-associated stromal cells and adenocarcinoma cells were centrifuged and resuspended separately in Dulbecco's Modified Eagle Medium (DMEM/F12) (Gibco; Thermo Fisher Scientific, CA, USA) medium containing 10\% FBS and supplemented with $100 \mathrm{U} / \mathrm{mL}$ penicillin/streptomycin. The adenocarcinoma cells were used in the current study. Cells were grown in $5 \% \mathrm{CO} 2$ at $37{ }^{\circ} \mathrm{C}$. Cells were passaged at $80 \%$ confluence up to four times.

\section{Development of Resistant Cell Lines}

The MFE319 and MFE296 cell lines were chosen for the current study due to their stability and their definitive EEC phenotypic classification. ${ }^{24}$ MFE319 and MFE296 cells have been reported as having relatively higher levels of hormone receptor (PR, PR-B and ER) levels, making them a suitable model for studying hormonal responses in cell culture. ${ }^{25}$ To develop a high-level laboratory model of resistance, ${ }^{26}$ the MFE296 ${ }^{\mathrm{R}}$ and MFE319 ${ }^{\mathrm{R}}$ cells were treated every 2 days with this concentration of LNG with no escalation. Resistance was then assessed via an $\mathrm{IC}_{50}$ and then determined through the observation of fold change. MFE296 and MFE319 cells were trypsinised, counted, and seeded on to a 96 well plate at a concentration of $3 \times 10^{5}$ cells $/ \mathrm{mL}$. Following a $24 \mathrm{~h}$ incubation at $5 \% \mathrm{CO} 2$ at $37^{\circ} \mathrm{C}$, cells were treated with escalating LNG (SigmaAldrich \# 797-63-7) dissolved in dimethyl sulfoxide (DMSO, final concentration no greater than 0.001\%) (Sigma-Aldrich \#D5879, CA, USA) concentrations from $0-500 \mu \mathrm{M}$ and incubated for a further $24 \mathrm{~h}$. Plates were then analysed using the Cell Counting Kit-8 (CCK8) (Dojindo \#CK04-11) according to manufacturer's instructions. Readings at $450 \mathrm{~nm}$ were obtained after 3 hours using the Thermo Scientific TM Multiskan GO TM Microplate Spectrophotometer (Thermo Fisher Scientific, MA, USA). Any increase in absorbance indicated an increase in cell density. LNG treatment concentration for resistant clone development was identified as the point of $30 \%$ cell viability for each cell line.
LNG-resistant MFE319, MFE296 and primary cell lines were obtained from parental cells via continuous exposure to LNG dissolved in 0.001\% DMSO. MFE296 cells were treated with $450 \mu \mathrm{M}$ LNG, MFE319 with $350 \mu \mathrm{M}$ LNG and primary cells with $100 \mu \mathrm{M}-200 \mu \mathrm{M}$ LNG. A DMSO control was created for each cell line at a dose of $0.001 \%$ dissolved in respective culture media.

A kill curve was used to confirm resistance. Following an LNG treatment period of 4 months, cells were trypsinised, counted, and seeded on to a 96 well plate at a concentration of $3 \times 10^{5}$ cells $/ \mathrm{mL}$ for the LNG-sensitive cells and $6 \times 10^{5}$ cells $/ \mathrm{mL}$ for the LNG-resistant cells of both MFE296 and MFE319 cell lines. Cells were incubated at $5 \% \mathrm{CO} 2$ at $37{ }^{\circ} \mathrm{C}$ for $24 \mathrm{~h}$ and then treated with escalating LNG concentrations from 0 to $2000 \mu \mathrm{M}$ and incubated for a further $24 \mathrm{~h}$. Following incubation plates were analysed using CCK8 according to manufacturer's instructions.

Cell lines from here on will be referred to as MFE296 ${ }^{\mathrm{R}}$ (LNG-resistant), MFE296 ${ }^{\mathrm{S}}$ (LNG-sensitive) and MFE319 ${ }^{\mathrm{R}}$ (LNG-resistant), MFE319 ${ }^{\mathrm{S}}$ (LNG-sensitive).

\section{Proliferation Assay}

Cell proliferation was carried out according to previous studies. ${ }^{27}$ Cells were seeded in triplicate onto a 96-well plate at a concentration of $3 \times 10^{5}$ cells $/ \mathrm{mL}\left(\right.$ MFE296 ${ }^{\mathrm{R}}$, MFE2 $96^{\mathrm{S}}$ and MFE319 ${ }^{\mathrm{R}}$, MFE319 ) and incubated at $5 \%$ $\mathrm{CO} 2$ at $37{ }^{\circ} \mathrm{C}$ for 24 hours. Following incubation plates were analysed using CCK8 according to manufacturer's instructions. Readings were obtained at 0-, 24-, 48- and 72hour time points. All absorbance values were normalised to the T0 time point to give the normalised proliferation of each cell line.

\section{Transwell Migration Assay}

Cell migration was measured via the Boyden Chamber assay according to a previous study. ${ }^{27}$ Transwells (6.5-mm) with $8.0-\mu \mathrm{m}$ pore polycarbonate membrane inserts (Sigma-Aldrich \#CLS3422, NSW Australia) were used according to manufacturer's instructions. Cells were seeded in transwell inserts at a concentration of $3 \times 10^{5}$ cells/mL for MFE296 ${ }^{\mathrm{R}}$ and MFE296 $6^{\mathrm{S}}$ and $1 \times 10^{6}$ cells/ $\mathrm{mL}$ for MFE319 ${ }^{\mathrm{R}}$, and MFE319 $9^{\mathrm{S}}$ and incubated for 48 hours at $5 \% \mathrm{CO} 2$ at $37^{\circ} \mathrm{C}$. Following incubation, cells were washed twice with PBS and fixed with $100 \%$ ethanol at room temperature for 20 minutes and stained with $1 \%$ crystal violet at room temperature for 15 minutes. Following staining, transwells were washed twice with 
PBS and non-migrated cells were wiped off using a cotton swab. The membrane was then removed and mounted on a glass slide. Micrographs were taken of four quadrants of the membrane to accurately represent the entire membrane and the cell number was counted using ImageJ (Java Software, ${ }^{28}$ WI, USA). An average cell count of the four quadrants was used in statistical analysis.

\section{Wound Migration Assay}

Cell migration was measured via a wound healing assay. MFE296 and MFE319 cell lines were plated onto a six-well plate at a concentration of $1 \times 10^{6}$ cells $/ \mathrm{mL}$ and incubated at $5 \% \mathrm{CO} 2$ at $37^{\circ} \mathrm{C}$ for 24 hours. Following incubation, a $10 \mathrm{uL}$ pipette tip was used to create a scratch through the centre of each well. Micrographs of the plates were taken at 0-, 24-, 48-, 72- and 96-hour time points using a 10× objective lens. Wound healing and the percentage of open area was measured using TScratch (CSElab software, ZH, Switzerland). ${ }^{29}$

\section{Invasion (3D Tumour Spheroid)}

Cell invasion was measured using a three-dimensional (3D) tumour spheroid invasion assay and carried out according to previous studies. ${ }^{30}$ Hanging drop cultures were prepared on a six-well plate using a cell concentration of $8 \times 10^{4}$ cells $/ \mathrm{mL}$ for MFE296 $6^{\mathrm{S}}$ and MFE296 ${ }^{\mathrm{R}}$, and $3 \times 10^{4}$ cells $/ \mathrm{mL}$ for both MFE319 ${ }^{\mathrm{S}}$ and $\mathrm{MFE} 319^{\mathrm{R}}$ and incubated for 96 hours. Following incubation, once spheroids were visible they were embedded into a matrix of $3 \mathrm{mg} / \mathrm{mL}$ type I collagen (rat tail) (Gibco; Thermo Fisher Scientific \#A10483-01, NSW Australia) and $2.7 \mathrm{mg} / \mathrm{mL}$ matrigel (Corning Life Sciences \#354234, MA, USA) matrix. Micrographs were taken to monitor invasion at 0 , 24, 48, 72 and 96 hours following plating using the $20 \times$ objective lens. Spheroid invasion was then measured as the total area of spheroids using ImageJ (Java Software). ${ }^{28}$

\section{D Adhesion Assay}

Cell adhesion was carried out according to previous studies. $^{31}$ Adhesion was measured against collagen type I (rat tail) (Gibco; Thermo Fisher Scientific). Tissue culture plates were coated with collagen $(10 \mu \mathrm{g} / \mathrm{mL})$ and $3 \%$ bovine serum albumin (BSA), as the negative control, in PBS. Coated plates were incubated for $24 \mathrm{~h}$ at $37^{\circ} \mathrm{C}$ and then rinsed with $80 \%$ ethanol. Three percent BSA in PBS was added to each well and incubated for a further $30 \mathrm{~min}$ at $37{ }^{\circ} \mathrm{C}$. After rinsing with PBS, concentrations of $5 \times 10^{5}$ cells $/ \mathrm{mL}$ for all cell lines in serum-free media were added to the coated plates and left to adhere at $37{ }^{\circ} \mathrm{C}$ for 1 h. Following incubation, plates were washed 3 times with PBS and fixed with $100 \%$ ethanol before being stained with $0.1 \%$ crystal violet at room temperature for $30 \mathrm{~min}$. Plates were then washed extensively with water to remove excess staining and then left to dry. Once dried, cells were lysed with 50\% acetic acid. Absorbance was measured at 595nm using the Thermo Scientific TM Multiskan GO ${ }^{\mathrm{TM}}$ Microplate Spectrophotometer.

\section{Literature Search}

A literature search was carried out to identify a set of key genes involved in progesterone resistance when treating endometrial cancer or endometrial hyperplasia. SCOPUS, PubMed and Google Scholar were searched for the following keywords ("endometrial cancer*" OR "endometrial carcinoma*" OR "endometrial neoplasm*") AND (IUD OR “intra-uterine-device*" OR IUS OR progesterone OR progestin OR Levornogestrel OR "intra-uterine device*" OR "intrauterine system*" OR "intra-uterine system*" OR Mirena) AND ("Biomarkers" OR "Marker" or "Predictive Marker*") AND ("Response")). Articles were critically assessed and genes were selected due to their implication in progesterone resistance in endometrial cancer (EC) and hyperplasia treatment. A review outlining these papers, has been written. ${ }^{19}$ From this, 13 genes were chosen for analysis: HOTAIR, HE4, ANO1, SOX17, CGNL1, DACH1, RUDC3B, SH3YL1, CRISPLD1, FOXO1, PR-B, ER, and $M S X 1$. A further five genes were selected due to their relationship to EC: $M D R 1, D K K 1, S A T B 2, C A C N A 2 D 3$ and KLF4.

\section{RNA Extraction}

RNA extraction was carried out according to a previous study. ${ }^{32}$ LNG-resistant cells and LNG-sensitive controls for MFE319, MFE296, GB\#13, GB\#16 and GB\#23 cells were harvested, pelleted, and the RNA from these cells extracted using the zymo Quick-RNA kit (Zymo cat\# R1057, CA, USA) according to the manufacturer's instructions. RNA quantification (in $\mathrm{ng} / \mu \mathrm{L}$ ) and purity was assessed using the NanoDrop spectrophotometer (Thermo Fisher Scientific). A 260/280 and 260/230 ratio of $\sim 2.0 \mathrm{~nm}$ was considered optimal "pure" RNA.

\section{RT-qPCR}

Conversion of RNA $(1 \mu \mathrm{g})$ to double-stranded cDNA was carried out using the QuantiTect ${ }^{\circledR}$ RT kit following the manufacturer's instructions (Qiagen \#205311). NCBI 
Primer Blast was used to create a list of potential primers for each of the genes (Supplementary Table 1). qPCR analysis was carried out according to previous studies. ${ }^{32}$ Twenty-five nanograms of cDNA, $100 \mathrm{nM}$ of primers and $12.5 \mu \mathrm{L}$ SYBRGreen master mix (Qiagen \# 204143) was used in each reaction. RT-qPCR cycling conditions were $95^{\circ} \mathrm{C}$ for $10 \mathrm{~min},\left(95^{\circ} \mathrm{C}\right.$ for 15 seconds, $60^{\circ} \mathrm{C}$ for 30 seconds, $72^{\circ} \mathrm{C}$ for 40 seconds) for a total of 40 cycles and then $95^{\circ} \mathrm{C}$ for 60 seconds, followed by melt curve analysis. $\mathrm{C}_{\mathrm{t}}$ values were analysed using the normalisation method against three reference genes: succinate dehydrogenase complex subunit (SDHA), 90-kDa heat shock protein 1 beta $(H S P C B)$ and $60 \mathrm{~S}$ ribosomal protein L13a $(R P L 13 A)$ to calculate the $\triangle \mathrm{Ct}(\triangle \mathrm{Ct}$ mRNA Ct geomean endogenous reference genes). $\Delta \Delta \mathrm{Ct}$ was then calculated relative to sensitive controls $\left(\Delta \mathrm{Ct}_{\text {(sample1) }}-\right.$ $\left.\Delta \mathrm{Ct}_{(\text {sample2) }}\right)$. Fold change was then calculated.

\section{Statistical Analysis}

All values are represented as mean \pm standard deviation (SD) unless otherwise stated. A $f$-test was used to determine variances in standard deviation prior to $t$-test analysis. An unpaired Student's $t$-test was carried out for determination of resistance, transwell migration and adhesion assays to compare values between LNG-resistant and LNG-sensitive cell lines. An unpaired Student's $t$-test was carried out on the mean of each time point for wound healing, migration and proliferation to give significance at each time point. Technical and biological triplicates $(n=3)$ were carried out for each experiment. A paired Student's $t$-test was performed on fold change values for differences in mRNA expression between LNG-resistant and LNG-sensitive MFE296, MFE319, GB\#23, GB\#52 and GB\#67 cell lines. A p value of $\leq 0.05$ was considered statistically significant. ${ }^{22}$ Analysis of TCGA mRNA expression data in endometrial cancer was conducted using UALCAN ${ }^{33}$ to investigate any relationships with clinical parameters.

\section{Results}

\section{Development of LNG-Resistant MFE296 and MFE3 19 Cell Lines}

Resistance was assessed via an $\mathrm{IC}_{50}$ and then determined through the observation of fold change. The $\mathrm{IC}_{50}$ values of MFE296 ${ }^{\mathrm{S}}$ and MFE296 ${ }^{\mathrm{R}}$ cells were $250 \mu \mathrm{M}$ and $1800 \mu \mathrm{M}$, respectively, and the fold change increase in resistance from MFE296 ${ }^{\mathrm{S}}$ and MFE296 ${ }^{\mathrm{R}}$ was 6 . The $\mathrm{IC}_{50}$ values of MFE $319^{\mathrm{S}}$ and MFE $319^{\mathrm{R}}$ cells were $250 \mu \mathrm{M}$ and $2000 \mu \mathrm{M}$, respectively, and the fold change increase in resistance from MFE319 $9^{\mathrm{S}}$ and MFE319 ${ }^{\mathrm{R}}$ was 8 (Supplementary Figure 1).

\section{LNG Resistance Impact on Cellular Proliferation in Immortalised Cell Lines}

There was no significant difference in cell proliferation between LNG-resistant cells and LNG-sensitive control cells apart from a significant decrease in MFE $319^{\mathrm{R}}$ absorbance and therefore, cell density at the 48-hour time point (MFE319 $^{\mathrm{S}}: 1.535 \pm 0.12, \quad$ MFE319 ${ }^{\mathrm{R}}: 1.23 \pm 0.07$ ) $(\mathrm{P}<0.05)$. Proliferation increased at a similar rate in both cell lines over a period of 72 hours. This observation was conserved in both LNG-treated cells and controls (Figure 1A and B). Significance was determined using an unpaired Student's $t$-test.

\section{LNG Resistance Impact on Migration in Immortalised Cell Lines}

A significant increase in wound migration was observed in the MFE296 ${ }^{\mathrm{R}}$ cell line at the T72 hour time points $\left(\right.$ MFE296 $\left.^{\mathrm{S}}: 9.33 \pm 0.018, \mathrm{MFE}^{296} 6^{\mathrm{R}}: 4.13 \pm 0.018\right)(\mathrm{p}=$ 0.0248 ) and T96 hour time points (MFE296 ${ }^{\mathrm{S}}$ : $6.65 \pm$ $\left.0.013, M^{2} 296^{R}: 1.44 \pm 0.010\right)(p=0.0106)$ compared to the MFE296 ${ }^{\mathrm{S}}$ control represented by a smaller \% open area. There was no significant difference in migration at any other time points (Figure 2A). There was no significant change in wound migration in the MFE319 ${ }^{\mathrm{R}}$ cell line compared to the MFE319 ${ }^{\mathrm{S}}$ control (Figure 2B). Representative images of wound healing can be seen in (Figure $2 \mathrm{C}$ and $\mathrm{D}$ ). There was no significant difference in Boyden chamber transwell migration between MFE296 ${ }^{\mathrm{R}}$ cells and MFE296 ${ }^{\mathrm{S}}$ cells (Figure 3A). However, a significant increase in transwell migration was observed in the MFE319 ${ }^{\mathrm{R}}$ cells compared MFE319 ${ }^{\mathrm{S}}$ cells (MFE319: $210.31 \pm 9.24$, MFE296 $^{\mathrm{R}}: 254.62 \pm 31.77$ ) (Figure 3B) $(\mathrm{P}=0.03)$. Representative images of transwell migration can be seen in (Figure $3 \mathrm{C}$ and $\mathrm{D}$ ).

\section{LNG Resistance Impact on Cellular Adhesion in Immortalised Cell Lines}

The adhesive capacity of LNG-resistant and LNG-sensitive cells was evaluated through the ability of respective cell lines to adhere to collagen in 1 hour. Adhesion was significantly attenuated in the MFE296 ${ }^{\mathrm{R}}$ cells (absorbance: $0.662 \pm 0.11$ ) compared to the MFE296 ${ }^{\mathrm{S}}$ cells (absorbance: $0.308 \pm 0.088$ ) after 1 hour $(\mathrm{p}=0.012)$ (Figure 4A). Adhesion was also attenuated in the MFE $319^{R}$ cells (absorbance: $0.822 \pm 0.18$ ) 
A

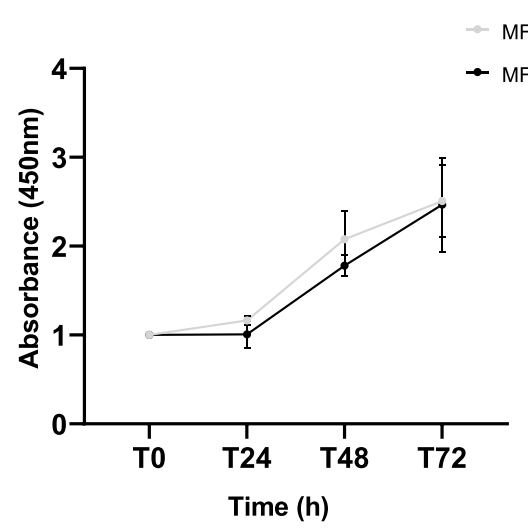

B

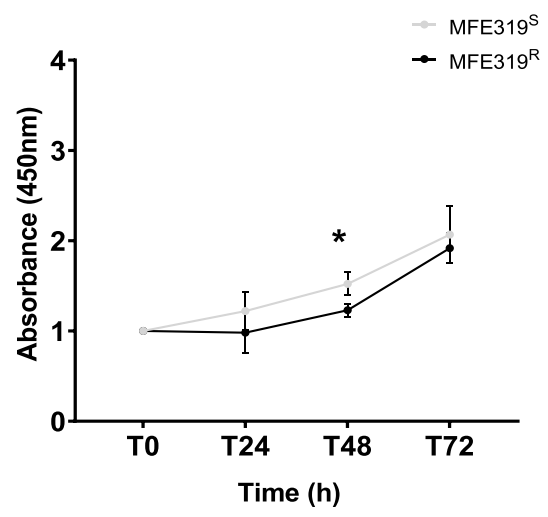

Figure I LNG-treated cells proliferate at the same rate as controls in immortalised cell lines. Proliferation assay results showing the difference in cell proliferation between (A) MFE296 ${ }^{\mathrm{R}}$ (black) and MFE296 ${ }^{\mathrm{S}}$ (grey) and (B) MFE3 $19^{\mathrm{R}}$ (black) and MFE319 (grey) cell lines, respectively. Proliferation rate is displayed as absorbance at $450 \mathrm{~nm}$ relative to LNGsensitive controls. (A) Proliferation rate does not differ between MFE296 ${ }^{R}$ and MFE296 $6^{S}$ cells. (B) Proliferation rate significantly decreased in the MFE31 $9^{R}$ cells at the $48 \mathrm{~h}$ time point compared to MFE $319^{S}$ cells. Results are expressed as mean \pm SD, results are done in triplicate $(n=3)$. Individual groups were analysed using $t$-test. $* P<0.05$.

compared to the MFE319 ${ }^{\mathrm{S}}$ cells (absorbance: $0.502 \pm 0.06$ ) after 1 hour $(\mathrm{p}=0.04)$ (Figure 4B). BSA served as a negative control for cell adhesion.

\section{LNG Resistance Impact on Invasion in Immortalised Cell Lines}

Cell invasion rate was measured via a 3D spheroid invasion assay embedded in an ECM matrix of collagen type I and matrigel. Spheroid size $\left(\mu \mathrm{m}^{2}\right)$ was photographed every $24 \mathrm{~h}$ for a total of $96 \mathrm{~h}$ and then measured using Image J. There was no significant difference in spheroid size $\left(\mu \mathrm{m}^{2}\right)$ in MFE296 ${ }^{\mathrm{R}}$ cells compared to MFE296 (Figure $5 \mathrm{~A}$ ) or in MFE319 ${ }^{\mathrm{R}}$ compared to MFE319 $9^{\mathrm{S}}$ cells (Figure 5B). Representative images of MFE296 and MFE319 spheroids can be seen in Figure 5C and D.

\section{LNG-Resistant Cells Express Different Levels of mRNA to LNG-Sensitive Cells in Immortalised Cell Lines}

Four DEGs in the MFE296 resistant cell line were identified. Relative mRNA expression of KLF4, SATB2, CGNL1 and DACH1 were significantly upregulated in MFE296 ${ }^{\mathrm{R}}$ compared to MFE296 ${ }^{\mathrm{S}}$ cells $(\mathrm{p}=0.0000$, 0.0296, 0.0271, 0.0242 respectively (Figure 6A). Relative expression of these genes in MFE296 ${ }^{\mathrm{R}}$ cells were KLF4: 10.1 \pm 0.7 , SATB2: $6.3 \pm 2.7$, DACH: $7.3 \pm 0.13$ and CGNL1: 16.3 \pm 7.6. Non-significant data for MFE296 cell lines can be viewed in Supplementary Table 2 . $\Delta$ Ct mRNA expression of significant DEGs in the MFE296 cell line can be viewed in Supplementary Figure 2A.
Five DEGs were identified in the MFE319 cell line. Relative mRNA expression of KLF4, SATB2, ANO1, HE4 and DACH1 were significantly upregulated in the MFE319 ${ }^{\mathrm{R}}$ compared to MFE319 $9^{\mathrm{S}}$ cells $(\mathrm{p}=0.0223$, $0.0189,0.0004,0.0077,0.0029$ respectively) (Figure 6B). Relative expression of these genes in MFE $319^{R}$ cells were KLF4: 5.0 \pm 1.7 , SATB2: $2.6 \pm 0.6$, ANO1: $4.0 \pm 0.5$, HE4: 2.0 0.3 . Non-significant data for MFE319 cell lines can be viewed in Supplementary Table 3. $\Delta$ Ct mRNA expression of significant DEGs in the MFE319 cell line can be viewed in Supplementary Figure 2B.

Relative mRNA expression of KLF4 was significantly amplified in primary $\mathrm{LNG}^{\mathrm{R}}$ cell lines compared to $\mathrm{LNG}^{\mathrm{S}}$ controls $(p=0.0213)$ (Figure 7). Relative expression of $\mathrm{KLF} 4$ in $\mathrm{LNG}^{\mathrm{R}}$ primary cells was $1.5 \pm 0.2$. Relative mRNA expression of ER was significantly downregulated in primary $\mathrm{LNG}^{\mathrm{R}}$ cell lines compared to $\mathrm{LNG}^{\mathrm{S}}$ controls $(\mathrm{p}=2 \mathrm{e}-6)$ Relative expression of $\mathrm{ER}$ in $\mathrm{LNG}^{\mathrm{R}}$ primary cells was $0.3 \pm 0.02$. Non-significant data for primary cell lines can be viewed in (Supplementary Table 4).

Bioinformatic analysis of KLF4 and SATB2 in EC TCGA mRNA data using UALCAN ${ }^{33}$ showed that KLF4 mRNA expression is significantly decreased in EC primary tumours compared to healthy controls (Supplementary Figure 3A). There is no significant relationship between KLF4 and overall survival, weight or cancer stage (Supplementary Figure 3B-D). KLF4 mRNA expression is however significantly higher in patients aged between 40 and 60 years compared to patients between 60 and 100 years (Supplementary Figure 3E). SATB2 expression is significantly increased 
A

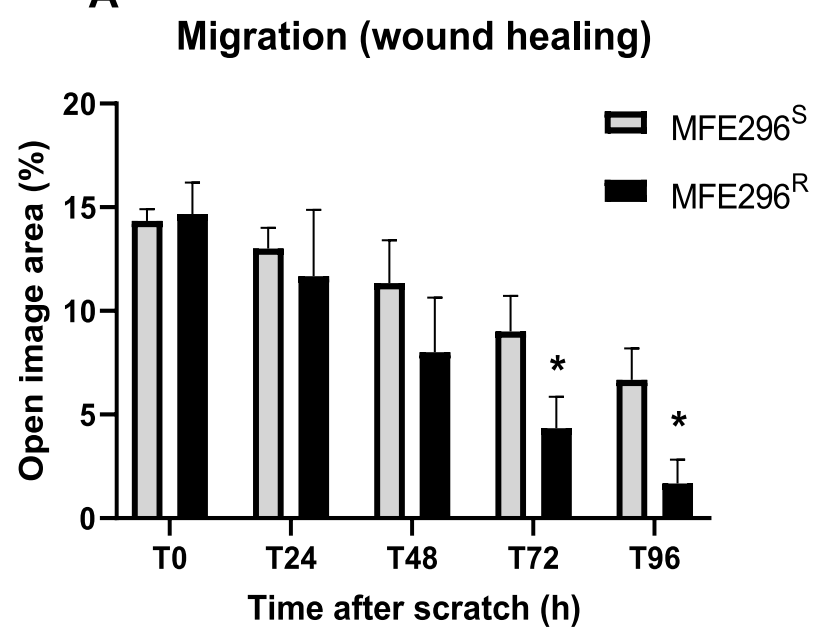

C

MFE296 5

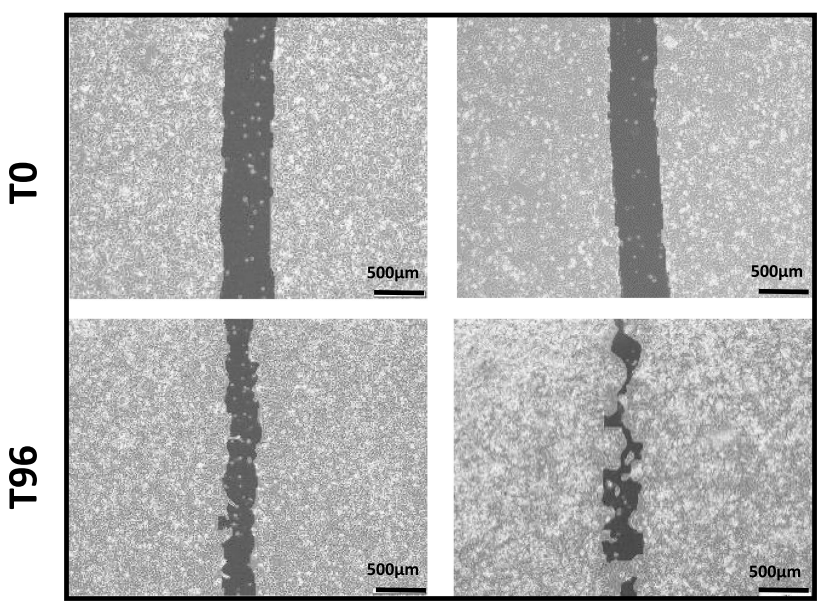

B

Migration (wound healing)

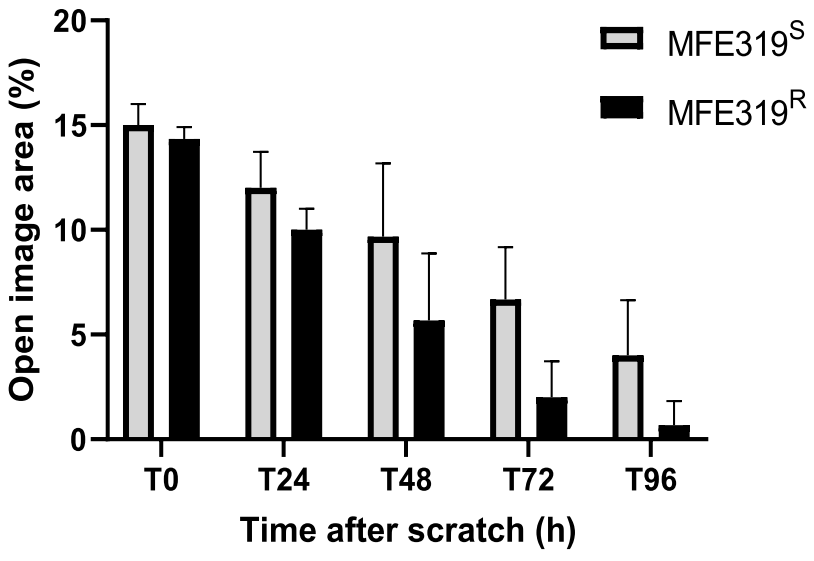

D MFE319s MFE319R

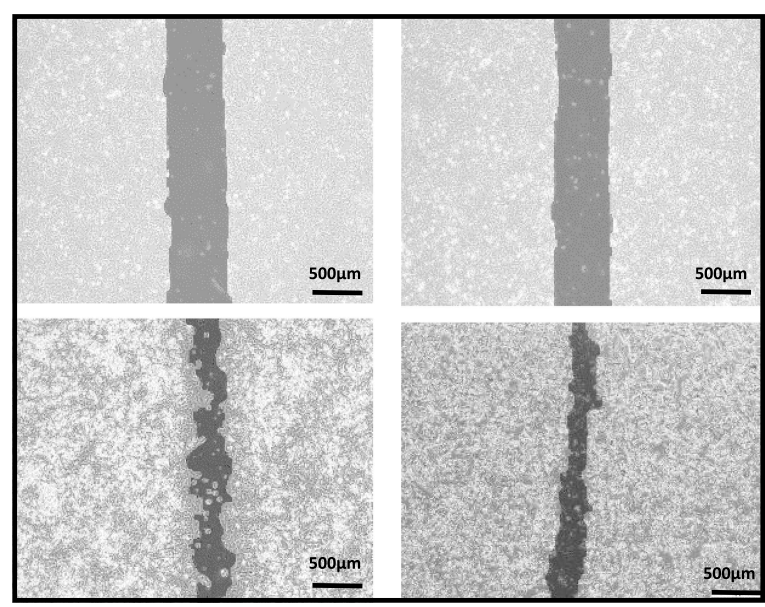

Figure 2 LNG resistance has some effect on migration in immortalised cell lines. (A) Wound migration assay results showing the difference between MFE296 ${ }^{\mathrm{S}}$ (grey) and MFE296 ${ }^{\mathrm{R}}$ (black) wound migration. Migration significantly increased in the MFE296 ${ }^{\mathrm{R}}$ cells at the $72 \mathrm{~h}$ time point compared to MFE296 ${ }^{\mathrm{S}}$ cells. Wound migration is displayed as $\%$ open area. (B) Wound migration assay results showing the difference between MFE $319^{\mathrm{S}}$ (grey) and MFE3 $19^{\mathrm{R}}$ (black) wound migration. MFE3। $9^{\mathrm{R}}$ and MFE3 $19^{\mathrm{S}}$ cell lines Wound migration significantly decreased in MFE3 $19^{R}$ cells at the $24 \mathrm{~h}$ time point. (C) Representative images of wound healing in MFE296 ${ }^{\mathrm{S}}$, MFE296 ${ }^{\mathrm{R}}$ cells taken using $10 \times$ objective. Yellow lines represent the \% open area. (D) Representative images of wound healing in MFE3 $19^{\mathrm{S}}$, MFE $319^{R}$ cells taken using $10 \times$ objective. Results are expressed as mean $\pm S D$, experiments performed in triplicate $(n=3)$. Individual groups were analysed using $t$-test. *P $<0.05$.

in EC primary tumours compared to healthy controls (Supplementary Figure 4A). There is no significant relationship between SATB2 and overall survival, age or weight; however, expression of SATB2 is significantly higher in stage 1,2 and 3 cancers in comparison to stage 4 cancers (Supplementary Figure 4B-E).

\section{Discussion}

The current study aimed to build a behavioural profile of LNG-resistant cell lines and identify significant DEG's in LNG-resistant cells compared to LNG-sensitive cell lines. LNG resistance did not affect proliferation or invasion in both MFE296 $^{\mathrm{R}}$ and MFE319 ${ }^{\mathrm{R}}$ cell lines; however, it significantly increased transwell migration in MFE319 ${ }^{\mathrm{R}}$ cells, increased wound healing migration at the $72-$ and 96-hour time points in MFE296 ${ }^{\mathrm{R}}$ cells and decreased cellular adhesion to collagen in MFE29 ${ }^{\mathrm{R}}$ cells and MFE319 cells. Transwell migration in MFE296 ${ }^{\mathrm{R}}$ cells was unaffected by LNG resistance.

Increased proliferation, migration, invasion and decreased adherence are all implicated in the epithelialmesenchymal transition (EMT) process. EMT is a physiological process involved in the early stage of carcinogenic dysregulation. ${ }^{34,35}$ During this process, cells begin to lose epithelial characteristics and acquire mesenchymal characteristics such as increased motility 
A

Migration (transwell)

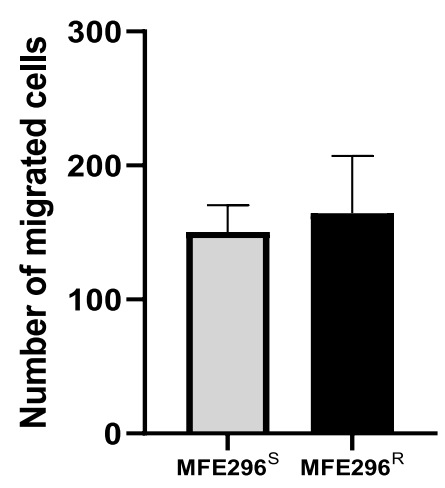

C

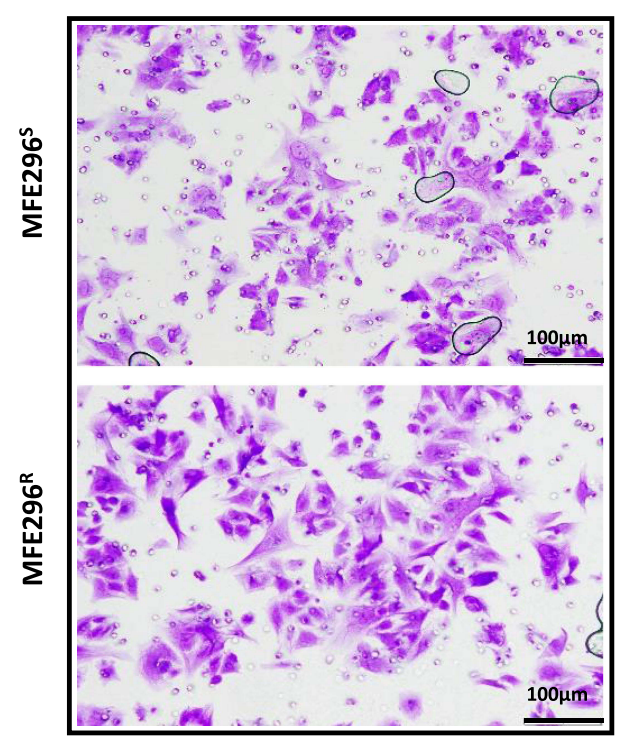

B

Migration (transwell)

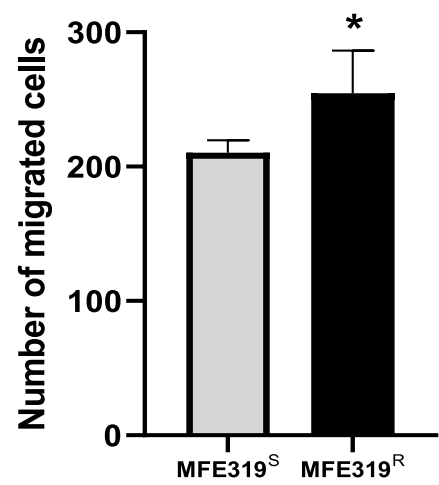

D

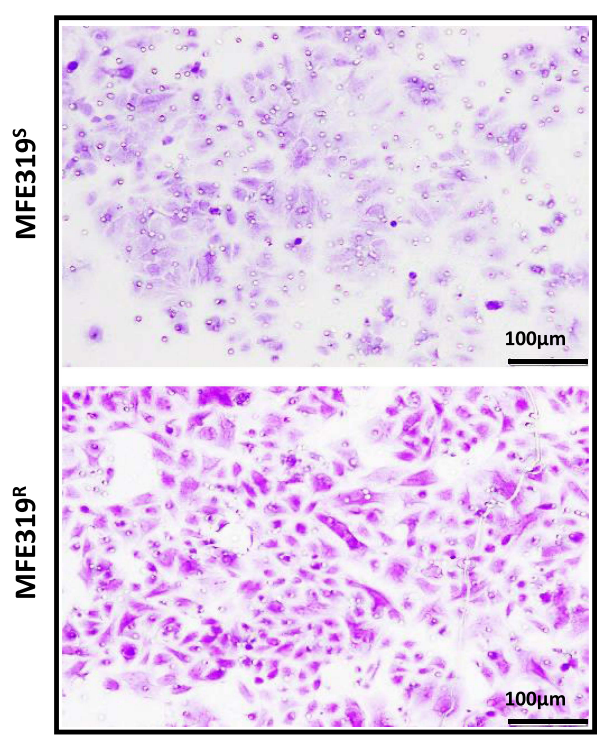

Figure 3 LNG resistance has some effect on migration in immortalised cell lines. (A) Transwell migration assay results showing the difference in MFE296 ${ }^{\mathrm{S}}$ (grey) and MFE296 ${ }^{\mathrm{R}}$ (black). Transwell migration rate does not differ between the MFE296 ${ }^{\mathrm{R}}$ and MFE296 ${ }^{\mathrm{S}}$ cells. (B) Transwell migration assay results showing the difference in MFE31 $9^{\mathrm{S}}$ (grey) and MFE3 $19^{R}$ (black) cell lines respectively. Migration significantly increased in the MFE3I $9^{R}$ cells compared to MFE3I $9^{\mathrm{S}}$ cells. (C) Representative images of MFE296 ${ }^{\mathrm{S}}$ and MFE296 ${ }^{R}$ cell transwell migration taken using $20 \times$ objective. (D) Representative images of MFE3 $19^{S}$ and MFE3 $19^{R}$ cell transwell migration taken using $20 \times$ objective Transwell migration is displayed as number of migrated cells on a transwell membrane (average of four quadrant counts). Results are expressed as mean \pm SD, experiments performed in triplicate $(n=3)$. Individual groups were analysed using $t$-test. $* P<0.05$.

through the reprogramming of gene expression. ${ }^{34}$ Acquisition of EMT phenotype has been previously associated with drug resistance, which could make these tumours more likely to metastasise or recur following treatment. $^{36}$ This is consistent with the results from the current study, showing that the LNG-resistant cells may be slightly more aggressive and, therefore, have more oncogenic potential than their LNG-sensitive counterparts. Clinically, this research is warranted as it is the first time the behavioural profile of LNG-resistant cells has been investigated. It is vital to understand if LNG-resistant cells behave differently as this could lead to alternative treatment pathways for women who are resistant to the LNG-IUS. This further demonstrates a need to identify women who will not respond to the LNG-IUS prior to treatment.

Seventeen potential biomarkers were identified in the literature and mRNA expression was investigated in LNGresistant and LNG-sensitive cell lines. Expression of both KLF4 and SATB2 was significantly upregulated in resistant cell lines $\left(\right.$ MFE296 ${ }^{\mathrm{R}}$ and MFE319 ${ }^{\mathrm{R}}$ ) compared to $\mathrm{LNG}^{\mathrm{S}}$ controls, suggesting that these genes have the 
A

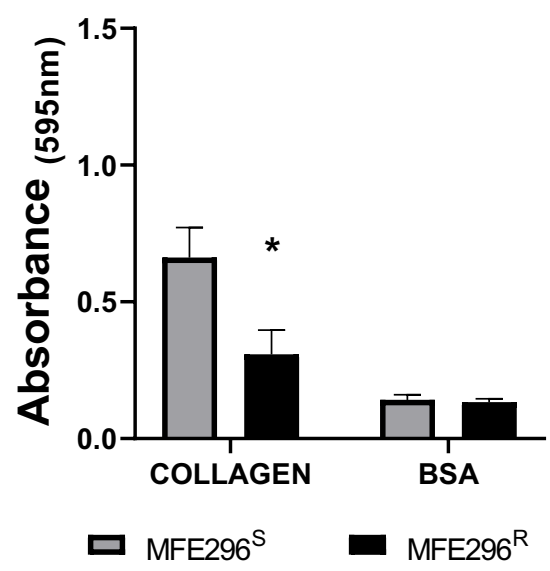

B

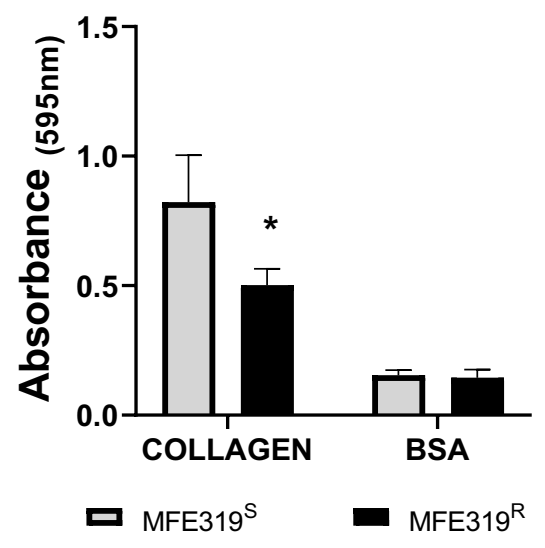

Figure 4 LNG resistance decreases adhesion in immortalised cell lines. Adhesion assay results showing the difference in cell adhesion. (A) MFE296 ${ }^{\mathrm{S}}$ (grey) and MFE296 ${ }^{\mathrm{R}}$ (black) and (B) MFE319S (grey) and MFE319R (black) cell lines, respectively. (A) Adhesion is significantly decreased in the MFE296 ${ }^{\mathrm{R}}$ cells compared to MFE296 ${ }^{\mathrm{S}}$ cells. (B) Adhesion is significantly decreased in MFE $319^{R}$ cells compared to MFE31 $19^{S}$ cells. Adhesion is displayed as Absorbance of crystal violet at $595 \mathrm{~nm}$. BSA served as a negative control. Results are expressed as mean $\pm \mathrm{SD}$, experiments performed in triplicate $(n=3)$. Individual groups were analysed using $t$-test. $* P<0.05$.

potential to serve as predictive biomarkers for response to the LNG-IUS. In the current study, upregulation of ANO1 in $\mathrm{MFE} 319^{\mathrm{R}}$ cell lines and upregulation of CGNL1 MFE296 ${ }^{\mathrm{R}}$ cells compared to LNG-sensitive controls supports previous findings from $\mathrm{Li}$ et $\mathrm{al}^{22}{ }^{22}$ where upregulation of these genes was observed in MPA-resistant Ishikawa cell lines. The current study did not observe these genetic upregulations across both cell lines, nor did it observe upregulation of DACH1, RUNDC3B, SH3YL1 or CRISPLD1 in LNG-resistant cells compared to LNGsensitive controls seen in the Li et al's ${ }^{22}$ study. The current study builds upon the Li et al's study by identifying ANO1 and CGNL1 upregulation in further EEC immortalised cell lines and observing these genetic changes in relation to LNG treatment specifically. The findings of the current study do not support observations made by Orbo et al, and Behrouzi et al, ${ }^{14,37}$ who identified low protein expression of HE4 to be associated with a positive response to the LNG-IUS. In the current study, no significant change in HE4 $\Delta \mathrm{Ct}$ mRNA expression in immortalised or primary LNG-resistant cells compared to LNG-sensitive controls was detected. However, the current study only investigated mRNA expression of HE4, rather than changes in protein expression observed by previous studies ${ }^{14,37}$ and it is not yet clear whether changes in $\triangle \mathrm{Ct}$ mRNA expression of HE4 directly correlate to HE4 protein expression. The differential mRNA expression observed between the two cell lines and primary cell lines in the current study, alongside the cell lines and patient samples used in previous studies, can most likely be attributed to tumour heterogeneity. The degree of spatial diversity within an individual's tumour is highly variable ${ }^{38}$ with research showing between 0 and 8000 heterogeneous coding mutations within primary tumours. ${ }^{39}$ This heterogeneity drives phenotypic variation, thus, posing a significant challenge to the diagnosis, management and treatment of cancer, alongside contributing to significant challenges when identifying biomarkers to guide clinical decision-making in cancer medicine. ${ }^{40}$ A panel biomarker approach with clinically validated cut-off points may be more appropriate to address these inter-tumour disparities. However, the current study serves as an exploratory investigation into genes that can be further investigated in a clinical setting.

This is the first time KLF4 and SATB2 have been investigated in the context of predictive biomarkers for EEC treatment and therefore serve as novel potential biomarkers that warrant further investigation. Of note, KLF4 appears to be the most promising potential biomarker due to its increase in mRNA expression in LNG-resistant cells conserved across both immortalised and primary cell lines. KLF4 is a member of the zinc finger containing Krüppellike factor family. ${ }^{41}$ It is involved in the regulation of diverse physiological functions and cellular processes such as cellular growth, proliferation, differentiation and somatic cell reprogramming. ${ }^{41}$ KLF4 has been identified to play an important role in the pathogenesis of many cancers. ${ }^{41}$ KLF4 has been previously identified as playing a role in anti-cancer drug resistance in cancers including nasopharyngeal, ${ }^{42}$ prostate, ${ }^{43}$ colorectal, ${ }^{44}$ breast, ${ }^{45}$ thyroid $^{46}$ and multiple myeloma. ${ }^{47}$ While KLF4 has not 
A

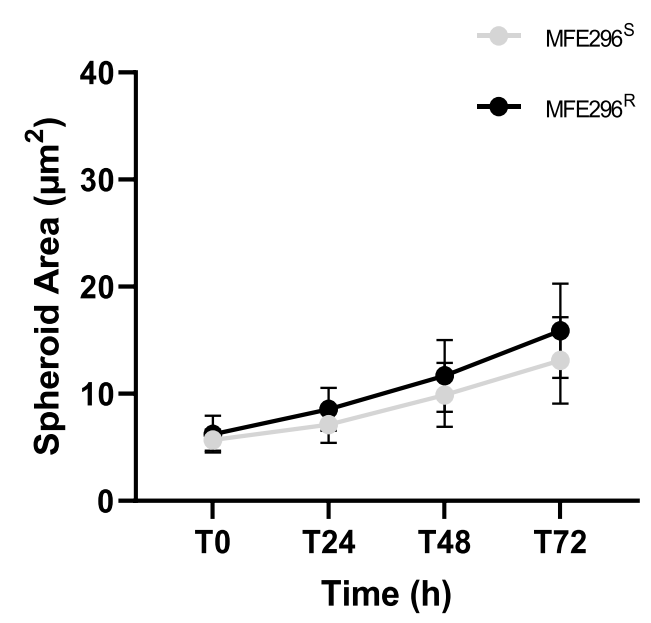

B

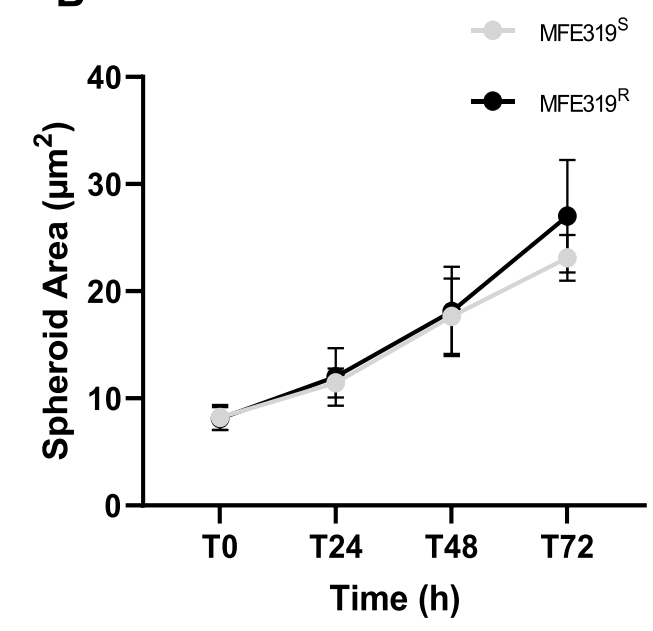

TO

C

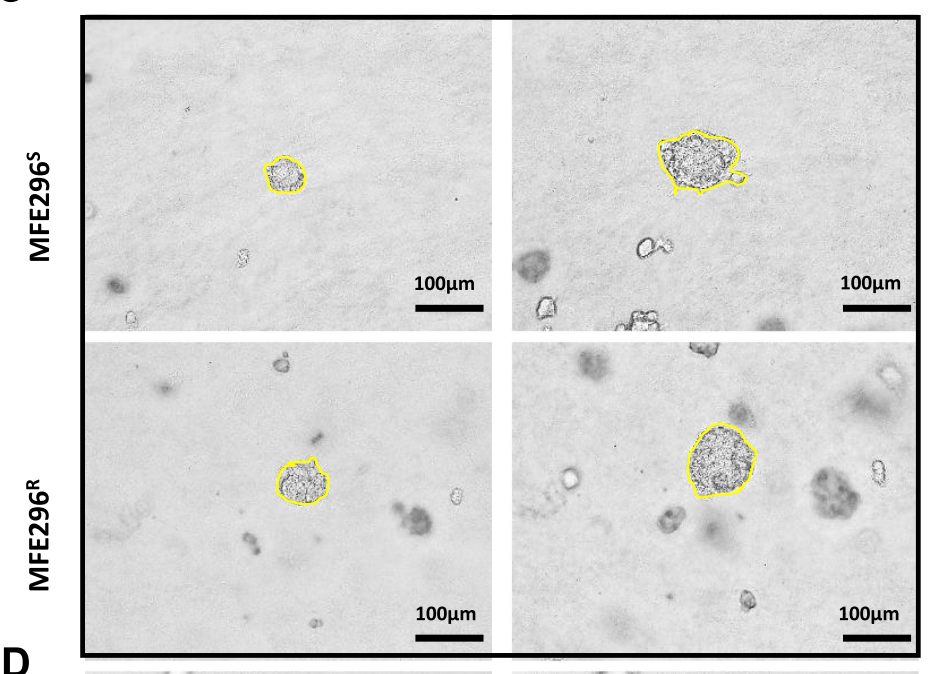

D

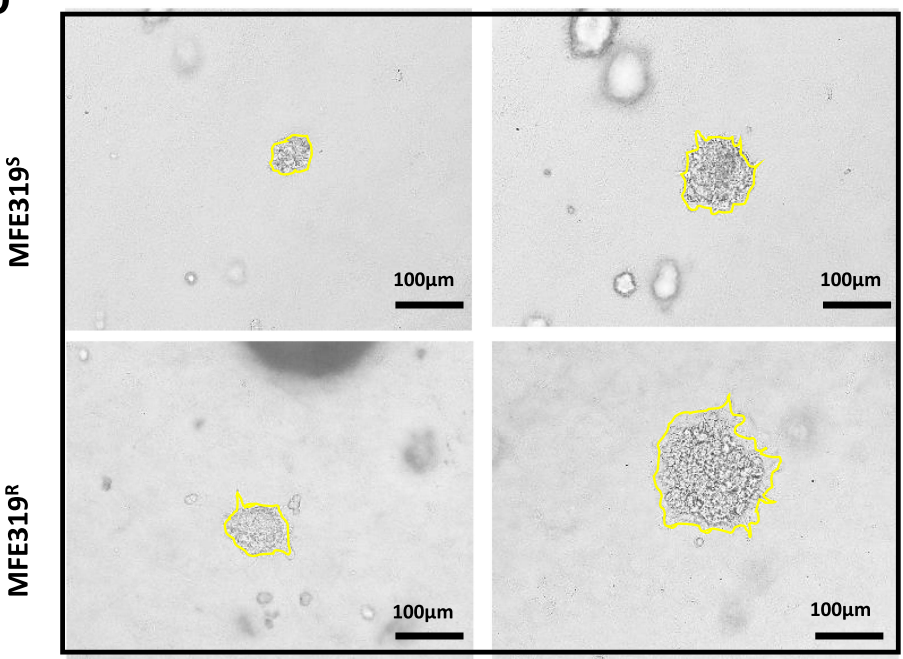

Figure 5 LNG resistance does not affect invasion in immortalised cell lines. Spheroid invasion assay results showing no significant difference in cell invasion. (A) Average spheroid size $\left(\mu \mathrm{m}^{2}\right)$ of MFE296 ${ }^{\mathrm{S}}$ (grey) and MFE296 ${ }^{\mathrm{R}}$ (black) over 72 hours. There is no significant change in spheroid size between LNG-resistant cells and LNG-sensitive cells. (B) Average spheroid size $\left(\mu \mathrm{m}^{2}\right)$ of MFE319 $9^{S}$ (grey) and MFE319 ${ }^{R}$ (black) over 72 hours. There is no significant change in spheroid size between LNG-resistant cells and LNG-sensitive cells. (C) Representative images of MFE296 ${ }^{\mathrm{S}}$ and MFE296 ${ }^{\mathrm{R}}$ spheroids. (D) Representative images of MFE3 I $9^{\mathrm{S}}$ and MFE3 I $9^{\mathrm{R}}$ spheroids. Images taken using the $20 \times$ objective. Yellow lines represent the area of the spheroid $\left(\mu \mathrm{m}^{2}\right)$. Results are expressed as mean \pm SD, experiments performed in triplicate $(\mathrm{n}=3)$. Individual groups were analysed using $t$-test.

been investigated as a biomarker in EC, mRNA expression of KLF4 has previously been seen to increase in the presence of progesterone receptor agonists such as progesterone and dienogest (synthetic progestin) in endometrial epithelial cells. ${ }^{48}$ This is consistent with observed results in the current study. The molecular relevance of KLF4 in LNG resistance is unknown; however, it may be down to the role KLF4 plays in Wnt pathway antagonism, ${ }^{41}$ promotion of survival through suppression of $\mathrm{BAX}^{49}$ and $\mathrm{TP} 53^{50}$ or its role as a stem cell factor promoting epithelial-mesenchymal transition (EMT). ${ }^{41}$ KLF4 has previously been shown to inhibit the MAPK pathway. ${ }^{41}$ Inhibition of the MAPK pathway has been shown to increase nuclear PR protein in endometriosis, ${ }^{51}$ and PR expression increases responsiveness to progesterone therapy. ${ }^{20,21,52,53}$ Another potential mechanism of resistance is transcriptional repression of FOXO1 by KLF $4 .{ }^{54}$ While this relationship has only been investigated in glioblastoma, the relationship between FOXO1 and KLF4 is interesting as downregulation of FOXO1 mRNA levels has been shown to predict a negative response in EC and endometrial hyperplasia patients managed with the LNGIUS. $^{21}$ While the current study does not observe a significant decrease in FOXO1 mRNA expression, this relationship should be further investigated in the context of EC. 
A

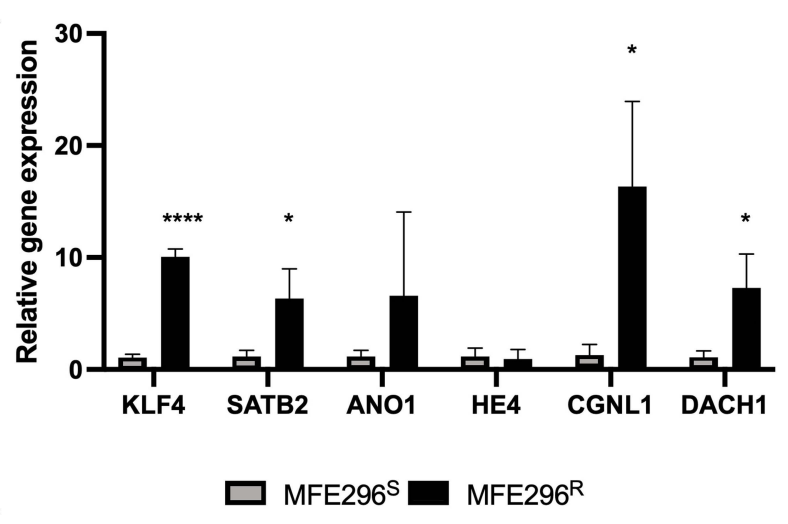

B

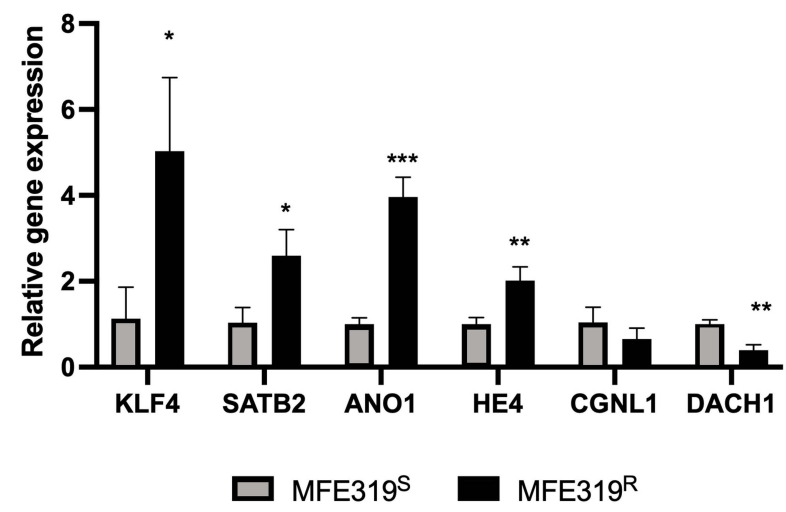

Figure 6 LNG-resistant cells express different levels of mRNA to controls in immortalised cell lines. RT-qPCR was performed in triplicate and $C_{t}$ values were normalised to three different housekeeping genes (SDHA, HSPCB, and RPLI3A). (A) Significant Relative mRNA expression of key genes in the MFE296 ${ }^{\mathrm{S}}$ (grey) and MFE296 ${ }^{\mathrm{R}}$ (black) cell lines. (B) Significant relative mRNA expression of key genes in the MFE $319^{\mathrm{S}}$ (black) and MFE3 $19^{\mathrm{R}}$ (black) cell lines. KLF4, SATB2, CGNLI and DACHI were all significantly upregulated in LNGresistant cells (black) compared to LNG-sensitive cells (grey) in MFE296 cells. KLF4, SATB2, ANOI and HE4 were all significantly upregulated and DACHI was significantly downregulated in LNG-resistant cells (black) compared to LNG-sensitive cells (grey) in MFE319 cells. Results are expressed as mean \pm SEM, experiments were performed in triplicate $(n=3)$. Individual groups were analysed using $t$-test. $* \mathrm{P}<0.05$, $* * \mathrm{P}<0.01$, $* * * \mathrm{P}<0.001$, $* * * * \mathrm{P}<0.0001$.

SATB2 is a nuclear matrix-associated transcription factor that is associated with abnormal expression in certain cancers but has not been reported in EC. ${ }^{55}$ Like KLF4, there is limited information available on the relevance of SATB2 in EC. Interestingly, SATB2 has been implicated as an upstream regulatory gene in endometrial leiomyomas through dysregulation of downstream genes associated with Wnt/beta catenin, TGF-beta growth factor signalling and retinoic acid signalling. ${ }^{56}$ In ovarian cancer, SATB2 is used to distinguish between ovarian tumour with mucinous features that may be of colorectal origin. ${ }^{57}$ No other research to date investigates the role of SATB2 in endometrial cancer or progesterone resistance. mRNA expression and relative protein expression of these genes should be analysed in further primary EEC samples to determine

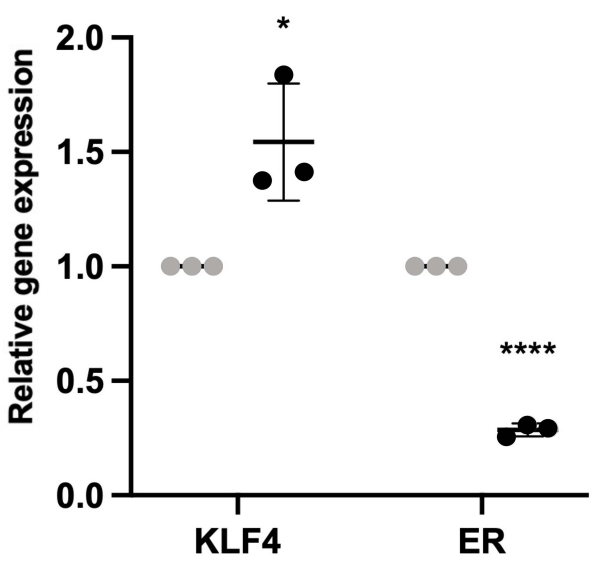

- LNGS • LNGR

Figure 7 LNG-resistant cells express different levels of mRNA to controls in primary cell lines. $\triangle \mathrm{Ct}$ mRNA expression of significant key genes in the $\mathrm{LNG}^{\mathrm{S}}$ (grey) and $L^{2} G^{R}$ (black) primary cell lines. RT-qPCR was performed in triplicate and $C_{t}$ values were normalised to three different housekeeping genes (SDHA, HSPCB, and RPLI3A). mRNA expression of KLF4 was amplified in all three primary LNG-resistant cell lines compared to LNG-sensitive controls, represented by a lower $\triangle \mathrm{Ct}$. mRNA expression of ER was downregulated amplified in all three primary LNG-resistant cell lines compared to LNG-sensitive controls represented by a higher $\Delta \mathrm{Ct}$. Results are expressed as mean $\pm \mathrm{SEM}$, experiments were performed in triplicate $(n=3)$. Individual groups were analysed using t-test. $* \mathrm{P}<0.05$, ****P $<0.0001$.

if they can serve as predictive biomarkers that can be used clinically.

Alongside the two DEGs identified in both MFE296 and MFE319 cell lines, the relative mRNA expression of hormone receptors ER and PR were measured in primary cell lines in the current study. Low expression of PR, both protein and mRNA, has been extensively shown in the literature to predict a negative response to progesterone treatment. $^{20,21,52,53}$ Contrary to the literature, the current study observed no significant change in mRNA expression of PR in all three primary LNG-resistant cells. Research has shown that LNG-IUS treatment can lead to downregulation of nuclear $\mathrm{PRs}^{58}$ therefore, despite previous research showing PR to have the potential to predict negative response to treatment, it would not make an efficacious predictive biomarker due to its expression being somewhat reliant on treatment. ${ }^{58}$ Alongside this, the two main subtypes of PR, PR-A and PR-B have been said to have opposing roles in estrogen-induced endometrial proliferation. ${ }^{59}$ PR-A has been said to inhibit proliferation, while PR-B contributes to it. The two receptor subtypes are also very difficult to differentiate via immunohistochemistry (IHC) and the use of antibodies that recognise both receptor subtypes should be used to evaluate overall 
PR expression in conditions including endometrial cancer. ${ }^{60}$ The current study only investigated PR-B expression; therefore, it would be beneficial to use RT-qPCR to investigate both subtypes further.

\section{Strengths and Limitations}

Limitations of the current study include a candidate-based approach rather than a discovery-based one. The genes investigated in the current study were chosen due to being previously implicated in progesterone resistance or other tumorigenic pathways of EC. A discovery-based approach would be to do whole-transcriptome sequencing, ${ }^{61}$ which could be efficacious in identifying novel targets that have not been previously described in the literature. However, within the confines of this preliminary study, a candidate-based approach was most appropriate.

The high-level laboratory model of resistance adopted in the current study was the most appropriate method in this case; however, the level of resistance obtained in the short time-frame was on the lower side of resistance. ${ }^{26}$ It is important to note that there may be differences between induced resistance, developed in the laboratory, and spontaneous resistance, which occurs in patients that are intrinsically resistant to the LNG-IUS. Because of this, the pathways implicated in acquired resistance after prolonged treatment could differ from pathways that altered resistance in drug-naïve cells. This is why it is important to first identify potential markers using a high-level laboratory model, and then to validate those findings in samples from women treated with the LNG-IUS and relate to outcome.

Due to being a 2D monolayer model, these assays do not represent what would occur physiologically, due to the lack of effect of both gravity and other surrounding tissues. This can lead the assays to lack predictivity ${ }^{62}$; however, the methods used for the behavioural analysis of resistant cell lines are high throughput and well documented, allowing us to compare methodology and results to other examples in the literature.

\section{Conclusion}

The need for conservative approaches to endometrial cancer treatment is rising due to the increase in incidence in women who may chose not to have surgery. Despite advances in molecular research, no clinically relevant predictive biomarkers have been established. We have identified six potential biomarkers in immortalised and primary patient cell lines for the use of the LNG-IUS treatment of early-stage EC. These markers should go on to be investigated further in patient cohorts to develop clinically relevant tissue and blood-based tests.

\section{Abbreviations}

DEG, differently expressed gene; EC, endometrial cancer; EEC, endometrioid endometrial cancer; EMT, epithelialmesenchymal transition; ER, estrogen receptor; IHC, immunohistochemistry; LNG, levonorgestrel; LNG-IUS, levonorgestrel intrauterine system; MPA, medroxyprogesterone acetate; PR, progesterone receptor.

\section{Ethics Approval and Consent to Participate}

The current study used primary cells derived from tissue samples of early-stage EC cultures donated by women as part of the Gynaecological Cancer Tissue Bank at Wellington hospital (Health and Disability Ethics Committees (HDEC) 15/CEN/143 and University of Otago health ethics committee H20/002). All patients provided written, informed consent prior to donation to the biobank.

\section{Acknowledgments}

We recognise and thank the women who donated tissue to gynaecological research. We acknowledge the pathologists at WSCL and clinicians involved in the gynaecological biobank.

\section{Author Contributions}

All authors made a significant contribution to the work reported, whether that is in the conception, study design, execution, acquisition of data, analysis and interpretation, or in all these areas; took part in drafting, revising or critically reviewing the article; gave final approval of the version to be published; have agreed on the journal to which the article has been submitted; and agree to be accountable for all aspects of the work.

\section{Funding}

University of Otago research grant was provided to $\mathrm{CH}$.

\section{Disclosure}

The authors declare that they have no competing interests. 


\section{References}

1. Ferlay J, Soerjomataram I, Dikshit R, et al. Cancer incidence and mortality worldwide: sources, methods and major patterns in GLOBOCAN 2012. Int $J$ Cancer. 2015;136(5):E359-E386. doi:10.1002/ijc. 29210

2. Duska LR, Garrett A, Rueda BR, Haas J, Chang Y, Fuller AF. Endometrial cancer in women 40 years old or younger. Gynecol Oncol. 2001;83(2):388-393. doi:10.1006/gyno.2001.6434

3. Gottwald L, Pluta P, Piekarski J, et al. Long-term survival of endometrioid endometrial cancer patients. Arch Med Sci. 2010;6 (6):937-944. doi:10.5114/aoms.2010.19305

4. Koh W-J, Abu-Rustum NR, Bean S, et al. Uterine neoplasms, version 1.2018, NCCN clinical practice guidelines in oncology. J Natl Compr Cancer Netw. 2018;16(2):170-199. doi:10.6004/jnccn.2018.0006

5. Pellerin GP, Finan MA. Endometrial cancer in women 45 years of age or younger: a clinicopathological analysis. Am J Obstet Gynecol. 2005;193(5):1640-1644. doi:10.1016/j.ajog.2005.05.003

6. McMahon MD, Scott DM, Saks E, Tower A, Raker CA, Matteson KA. Impact of obesity on outcomes of hysterectomy. J Minim Invasive Gynecol. 2014;21(2):259-265. doi:10.1016/j. jmig.2013.08.707

7. Acharya S, Esthappan J, Badiyan S, et al. Medically inoperable endometrial cancer in patients with a high body mass index (BMI): patterns of failure after 3-D image-based high dose rate (HDR) brachytherapy. Radiother Oncol. 2016;118(1):167-172. doi:10.1016/ j.radonc.2015.12.019

8. Setiawan VW, Yang HP, Pike MC, et al. Type I and II endometrial cancers: have they different risk factors? J Clin Oncol. 2013;31 (20):2607-2618. doi:10.1200/JCO.2012.48.2596

9. Christensen K, Doblhammer G, Rau R, Vaupel JW. Ageing populations: the challenges ahead. Lancet. 2009;374(9696):1196-1208. doi:10.1016/S0140-6736(09)61460-4

10. Wilson C, Tobin S, Young R. The exploding worldwide cancer burden. Int J Gynecol Cancer. 2004;14(1):1-11.

11. Mountzios G, Pectasides D, Bournakis E, et al. Developments in the systemic treatment of endometrial cancer. Crit Rev Oncol Hematol. 2011;79(3):278-292. doi:10.1016/j.critrevonc.2010.07.013

12. Beatty MN, Blumenthal PD. The levonorgestrel-releasing intrauterine system: safety, efficacy, and patient acceptability. Ther Clin Risk Manag. 2009;5(3):561-574.

13. Pal N, Broaddus RR, Urbauer DL, et al. Treatment of low-risk endometrial cancer and complex atypical hyperplasia with the levonorgestrel-releasing intrauterine device. Obstet Gynecol. 2018;131(1):109-116. doi:10.1097/AOG.0000000000002390

14. Behrouzi R, Ryan NAJ, Barr CE, et al. Baseline serum HE4 but not tissue HE4 expression predicts response to the levonorgestrel-releasing intrauterine system in atypical hyperplasia and early stage endometrial cancer. Cancers. 2020;12(2):276. doi: $10.3390 /$ cancers 12020276

15. Westin SN, Fellman B, Sun CC, et al. Prospective Phase II trial of levonorgestrel intrauterine device: nonsurgical approach for complex atypical hyperplasia and early-stage endometrial cancer. Am J Obstet Gynecol. 2020;224(2):191-e1.

16. Janda M, Robledo KP, Gebski V, et al. Complete pathological response following levonorgestrel intrauterine device in clinically stage 1 endometrial adenocarcinoma: results of a randomized clinical trial. Gynecol Oncol. 2021;161(1):143-151. doi:10.1016/j. ygyno.2021.01.029

17. Gallos I, Alazzam M, Clark T, et al. Management of endometrial hyperplasia. Green-top guideline no. 67. In: RCOG/BSGE Joint Guideline. 2016. London: Royal College of Obstetricians and Gynaecologists;2016.
18. Barr CE, Crosbie EJ. Mirena coil is a suitable treatment of early-stage endometrial cancer in obese women. BJOG. 2020;127 (8): 1001 .

19. Dore M, Filoche S, Danielson K, Henry C. Efficacy of the LNG-IUS for treatment of endometrial hyperplasia and early stage endometrial cancer: can biomarkers predict response? Gynecol Oncol Rep. 2021;36:100732. doi:10.1016/j.gore.2021.100732

20. Janzen DM, Rosales MA, Paik DY, et al. Progesterone receptor signaling in the microenvironment of endometrial cancer influences its response to hormonal therapy. Cancer Res. 2013;73 (15):4697-4710. doi:10.1158/0008-5472.CAN-13-0930

21. Reyes HD, Carlson MJ, Devor EJ, et al. Downregulation of FOXO1 mRNA levels predicts treatment failure in patients with endometrial pathology conservatively managed with progestin-containing intrauterine devices. Gynecol Oncol. 2016;140(1):152-160. doi:10.1016/j. ygyno.2015.10.023

22. Li W, Wang S, Qiu C, et al. Comprehensive bioinformatics analysis of acquired progesterone resistance in endometrial cancer cell line. J Transl Med. 2019;17(1):58. doi:10.1186/s12967-019-1814-6

23. Barros FSV, Brosens JJ, Brighton PJ. Isolation and primary culture of various cell types from whole human endometrial biopsies. BioProtocol. 2016;6(22):e2028. doi:10.21769/BioProtoc.2028

24. Skok K, Maver U, Gradišnik L, Kozar N, Takač I, Arko D. Endometrial cancer and its cell lines. Mol Biol Rep. 2020;47 (2):1399-1411. doi:10.1007/s11033-019-05226-3

25. Qu W, Zhao Y, Wang X, et al. Culture characters, genetic background, estrogen/progesterone receptor expression, and tumorigenic activities of frequently used sixteen endometrial cancer cell lines. Clinica Chimica Acta. 2019;489:225-232. doi:10.1016/j. cca.2018.08.013

26. McDermott M, Eustace AJ, Busschots S, et al. In vitro development of chemotherapy and targeted therapy drug-resistant cancer cell lines: a practical guide with case studies. Front Oncol. 2014;4:40. doi:10.3389/fonc. 2014.00040

27. Henry C, Llamosas E, Knipprath-Meszaros A, et al. Targeting the ROR1 and ROR2 receptors in epithelial ovarian cancer inhibits cell migration and invasion. Oncotarget. 2015;6(37):40310-40326. doi:10.18632/oncotarget.5643

28. Schneider CA, Rasband WS, Eliceiri KW. NIH Image to ImageJ: 25 years of image analysis. Nat Methods. 2012;9(7):671-675. doi:10.1038/nmeth.2089

29. Gebäck T, Schulz MMP, Koumoutsakos P, Detmar M. TScratch: a novel and simple software tool for automated analysis of monolayer wound healing assays. BioTechniques. 2009;46(4):265-274. doi: $10.2144 / 000113083$

30. Vinci M, Box C, Eccles SA. Three-dimensional (3D) tumor spheroid invasion assay. J Vis Exp. 2015;99:e52686.

31. Henry C, Quadir A, Hawkins NJ, et al. Expression of the novel Wnt receptor ROR2 is increased in breast cancer and may regulate both $\beta$ catenin dependent and independent Wnt signalling. J Cancer Res Clin Oncol. 2015;141(2):243-254. doi:10.1007/s00432-014-1824-y

32. Henry C, Hacker N, Ford C. Silencing ROR1 and ROR2 inhibits invasion and adhesion in an organotypic model of ovarian cancer metastasis. Oncotarget. 2017;8(68):112727-112738. doi:10.18632/ oncotarget. 22559

33. Chandrashekar DS, Bashel B, Balasubramanya SAH, et al. UALCAN: a portal for facilitating tumour subgroup gene expression and survival analyses. Neoplasia. 2017;19(8):659. doi:10.1016/j. neo.2017.05.002

34. Lamouille S, Xu J, Derynck R. Molecular mechanisms of epithelial-mesenchymal transition. Nat Rev Mol Cell Biol. 2014;15 (3):178-196.

35. Feitelson MA, Arzumanyan A, Kulathinal RJ, et al. Sustained proliferation in cancer: mechanisms and novel therapeutic targets. Semin Cancer Biol. 2015;35:S25-S54. 
36. Singh A, Settleman J. EMT, cancer stem cells and drug resistance: an emerging axis of evil in the war on cancer. Oncogene. 2010;29 (34):4741-4751. doi:10.1038/onc.2010.215

37. Ørbo A, Arnes M, Lyså LM, Borgfelt C, Straume B. HE4 is a novel tissue marker for therapy response and progestin resistance in medium-and low-risk endometrial hyperplasia. $\mathrm{Br} J$ Cancer. 2016;115(6):725-730. doi:10.1038/bjc.2016.247

38. Bedard PL, Hansen AR, Ratain MJ, Siu LL. Tumour heterogeneity in the clinic. Nature. 2013;501(7467):355-364. doi:10.1038/nature12627

39. Stanta G, Bonin S. Overview on clinical relevance of intra-tumor heterogeneity. Front Med. 2018;5(85). doi:10.3389/fmed.2018.00085

40. Burrell RA, McGranahan N, Bartek J, Swanton C. The causes and consequences of genetic heterogeneity in cancer evolution. Nature. 2013;501(7467):338-345. doi:10.1038/nature12625

41. Ghaleb AM, Yang VW. Krüppel-like factor 4 (KLF4): what we currently know. Gene. 2017;611:27-37. doi:10.1016/j. gene.2017.02.025

42. Lung HL, Kan R, Chau WY, et al. The anti-tumor function of the IKK inhibitor PS1145 and high levels of p65 and KLF4 are associated with the drug resistance in nasopharyngeal carcinoma cells. Sci Rep. 2019;12064(9):1.

43. Jiang Z, Zhang Y, Chen X, Wu P, Chen D. Long non-coding RNA LINC00673 silencing inhibits proliferation and drug resistance of prostate cancer cells via decreasing KLF4 promoter methylation. J Cell Mol Med. 2020;24(2):1878-1892. doi:10.1111/jcmm.14883

44. Deng X, Kong F, Li S, et al. A KLF4/PiHL/EZH2/HMGA2 regulatory axis and its function in promoting oxaliplatin-resistance of colorectal cancer. Cell Death Dis. 2021;485(12):1-3.

45. Jia Y, Zhou J, Luo X, et al. KLF4 overcomes tamoxifen resistance by suppressing MAPK signaling pathway and predicts good prognosis in breast cancer. Cell Signal. 2018;42:165-175. doi:10.1016/j. cellsig.2017.09.025

46. Lee SI, Kim DK, Seo EJ, et al. Role of Krüppel-like factor 4 in the maintenance of chemoresistance of anaplastic thyroid Cancer. Thyroid. 2017;27(11):1424-1432. doi:10.1089/thy.2016.0414

47. Schoenhals M, Kassambara A, Veyrune JL, et al. Krüppel-like factor 4 blocks tumor cell proliferation and promotes drug resistance in multiple myeloma. Haematologica. 2013;98(9):1442. doi:10.3324/ haematol.2012.066944

48. Shimizu Y, Takeuchi T, Mita S, et al. Krüppel-like factor 4 mediates anti-proliferative effects of progesterone with G0/G1 arrest in human endometrial epithelial cells. $J$ Endocrinol Invest. 2010;33 (10):745-750. doi:10.1007/BF03346681

49. Ghaleb AM, Katz JP, Kaestner KH, et al. Krüppel-like factor 4 exhibits antiapoptotic activity following gamma-radiation-induced DNA damage. Oncogene. 2007;26(16):2365-2373. doi:10.1038/sj. onc. 1210022

50. Rowland BD, Bernards R, Peeper DS. The KLF4 tumour suppressor is a transcriptio na 1 repressor of p53 that acts as a context-dependent oncogene. Nat Cell Biol. 2005;7(11):1074-1082. doi:10.1038/ ncb1314
51. Eaton JL, Unno K, Caraveo M, et al. Increased AKT or MEK1/2 activity influences progesterone receptor levels and localization in endometriosis. J Clin Endocrinol Metab. 2013;98(12):E1871-E18. doi:10.1210/jc.2013-1661

52. Akesson E, Gallos ID, Ganesan R, et al. Prognostic significance of estrogen and progesterone receptor expression in LNG-IUS (Mirena ${ }^{\circledR}$ ) treatment of endometrial hyperplasia: an immunohistochemical study. Acta Obstet Gynecol Scand. 2010;89(3):393-398. doi:10.3109/00016340903556006

53. Fawzy M, Mosbah A, Zalata K, et al. Predictors of progestin therapy response in endometrial hyperplasia: an Immunohistochemical Study. Egypt J Fertil Steril. 2016;20(2):6-11. doi:10.21608/ egyfs.2016.19528

54. Tang G, Liu D, Xiao G, et al. Transcriptional repression of FOXO1 by KLF4 contribute $\mathrm{s}$ to glioma progression. Oncotarget. 2016;7 (49):81757-81767. doi:10.18632/oncotarget.13184

55. Uhlén M, Fagerberg L, Hallstrom BM. Tissue-based map of the human proteome. Science. 2015;347(6220):1260419. PubMed: 25613900. doi:10.1126/science. 1260419

56. Sato S, Maekawa R, Tamura I, et al. SATB2 and NGR1: potential upstream regulatory factors in uterine leiomyo mas. $J$ Assist Reprod Genet. 2019;36(11):2385-2397. doi:10.1007/s10815-019-01582-y

57. Moh M, Krings G, Ates D, Aysal A, Kim GE, Rabban JT. SATB2 expression distinguishes ovarian metastases of colorectal and appendiceal origin from primary ovarian tumors of mucinous or endometrioid type. Am J Surg Pathol. 2016;40(3):419-432. doi:10.1097/ PAS.0000000000000553

58. Sletten ET, Smaglyukova N, Ørbo A, Sager G. Expression of nuclear progesterone receptors (nPRs), membrane progesterone receptors (mPRs) and progesterone receptor membrane components (PGRMCs) in the human endometrium after 6 months levonorgestrel low dose intrauterine therapy. J Steroid Biochem Mol Biol. 2020;202:105701. doi:10.1016/j.jsbmb.2020.105701

59. Patel B, Elguero S, Thakore S, Dahoud W, Bedaiwy M, Mesiano S. Role of nuclear progesterone receptor isoforms in uterine pathophysiology. Hum Reprod Update. 2015;21(2):155-173. doi:10.1093/humupd/dmu056

60. Mote PA, Johnston JF, Manninen T, Tuohimaa P, Clarke CL. Detection of progesterone receptor forms A and B by immunohistochemical analysis. J Clin Pathol. 2001;54(8):624-630. doi:10.1136/ jcp.54.8.624

61. Yang X, Kui L, Tang M, et al. High-throughput transcriptome profiling in drug and biomarker discovery. Front Genet. 2020;11:19. doi:10.3389/fgene.2020.00019

62. Kapałczyńska M, Kolenda T, Przybyła W, et al. 2D and 3D cell cultures - a comparison of different types of cancer cell cultures. Arch Med Sci. 2018;14(4):910-919.

\section{Publish your work in this journal}

Cancer Management and Research is an international, peer-reviewed open access journal focusing on cancer research and the optimal use of preventative and integrated treatment interventions to achieve improved outcomes, enhanced survival and quality of life for the cancer patient.
The manuscript management system is completely online and includes a very quick and fair peer-review system, which is all easy to use. Visit http://www.dovepress.com/testimonials.php to read real quotes from published authors. 